\title{
Morphology and phylogenetic relationships of the Cyprus racer, Hierophis cypriensis, and the systematic status of Coluber gemo- nensis gyarosensis Mertens (Reptilia: Squamata: Colubrinae)
}

\author{
Urs UTIGER ${ }^{1} \&$ Beat SCHÄTTI ${ }^{2}$ \\ ${ }^{1}$ Eichstrasse 26, CH-8045 Zürich, Switzerland. E-mail: cypriensis@ herpetology.ch \\ 2 Apartado postal 383, San Miguel de Allende, Gto. 37700, República Mexicana.
}

Morphology and phylogenetic relationships of the Cyprus racer, Hierophis cypriensis, and the systematic status of Coluber gemonensis gyarosensis Mertens (Reptilia: Squamata: Colubrinae). - External morphology, skull bones, and hemipenis features of Hierophis cypriensis (Schätti) were examined and new lowland findings are reported. Morphological and molecular data confirm sister species status of the Cyprus racer vis-à-vis the western Mediterranean racers $H$. gemonensis (Laurenti) and $H$. viridiflavus (Lacépède). Apart from the Cyclades viper, Macrovipera schweizeri (Werner), H. cypriensis is the only endemic Mediterranean insular snake species. Coluber gemonensis gyarosensis Mertens from Gyaros Island (Cyclades) is a junior synonym of $H$. viridiflavus. This Aegean population, highly isolated from the continuous range of the species, was most probably introduced by human activity in historical times. Molecular data suggest validity of $H$. viridiflavus carbonarius (Bonaparte) for melanotic populations of the European whip snake including the Gyaros racer.

Key-words: Hierophis cypriensis - morphology - zoogeography - Cyprus Coluber gemonensis gyarosensis - Hierophis viridiflavus - phylogeny mtDNA (COI, 12S rRNA).

\section{INTRODUCTION}

Since the description of Coluber cypriensis Schätti, 1985, the systematically difficult racer taxon Coluber auct. underwent drastic taxonomic changes. Coluber Linnaeus, 1758 is a purely Nearctic genus. Old World racers and whip snakes formerly parading under Coluber auct. (e.g., Schätti \& Wilson, 1986) belong to at least four different genera, viz., Hemerophis Schätti \& Utiger, Hemorrhois Boie, Hierophis Fitzinger, and Platyceps Blyth (Schätti, 1986, 1987; Schätti \& Utiger, 2001).

In an unpublished thesis, Schätti (1988) briefly discussed presumed phylogenetic affinities of the Cyprus racer (or whip snake), stating that the in situ hemipenis shows strong resemblance to Hierophis spp. Schätti \& Sigg (1989b) formally referred Coluber cypriensis to the predominantly southern Palaearctic genus Hierophis Fitzinger in Bonaparte, 1834 with the type species $H$. viridiflavus (Lacépède). Böhme \& Wiedl (1994) figured an everted hemipenis of $H$. cypriensis and considered "[...] the 
overall phenetic similarity being greatest with $C$.[oluber] $(H$.) gemonensis" (Laurenti). However, these authors continued to refer the Cyprus racer to Coluber auct., and not to "the Hierophis section of Coluber".

Hierophis Fitzinger is made up of two European species (viz., H. gemonensis and $H$. viridiflavus) as well as $H$. caspius (Gmelin) from the Balkans, the eastern Mediterranean $H$. jugularis (L.) and $H$. schmidti (Nikolskij), the endemic $H$. cypriensis, and H. spinalis (Peters) from Central Asia to Korea (Schätti 1987, 1993; Schätti \& Utiger, 2001).

The systematic status of Coluber gemonensis gyarosensis Mertens, 1968 from Gyaros Island (Aegean Sea, Cyclades) is controversial (see Böhme, 1993). Schätti (1988) stated that this population cannot be separated from the western Mediterranean Hierophis viridiflavus as far as external morphology is concerned.

This paper describes external morphological features and osteological characters of Hierophis cypriensis, compiles the known distribution of this insular endemic, and provides sequence data for two mitochondrial genes, COI and $12 \mathrm{~S}$ rRNA. The objective of the present study is to clarify the phylogenetic relationships of the Cyprus racer as well as the validity and systematic status of the racer population from Gyaros Island.

\section{MATERIAL AND METHODS}

The material examined for the purpose of this study is deposited in The Natural History Museum (formerly British Museum, Natural History), London (BMNH), Department of Zoology, The Hebrew University, Jerusalem (HUJ), Muséum d'histoire naturelle, Geneva (MHNG), Naturhistorisches Museum, Vienna (NMW), and Zoologisches Museum und Forschungsinstitut Alexander Koenig, Bonn (ZFMK). The specimens are: BMNH 87.9.27.25 (ठ̊), "Cyprus, Lord Lilford" (leg. Guillemard, paratype). HUJ 3331 ( 9 ), Kykko Monastery (Panagía tou Kýkko), approx. 34 58'N 3244'E, c. 1'100 m a.s.l., Nicosia District, leg. Mavromoustakis; HUJ 3786 (ơ), "Polemedia Hills" (Polemidia), c. 200 m (600 ft.), Limassol, leg. Mavromoustakis. MHNG 2206.30 ( + ), between Arakapás and Kalokhorio, approx. 34 $51^{\circ} \mathrm{N} 33^{\circ} 06^{\prime} \mathrm{E}$, 470 m, Limassol, B. Schätti, 14 April 1983 (holotype); MHNG 2453.60 ( đ̊), between Kannaviou and Stavros tis Psokas, c. 750 m, Paphos, W. Teschner, 11 May 1989; MHNG 2618.99 (đ), between Germasógeia (Yermasoyia) and Akroúnta, approx. 3445'N 3306'E, c. 75 m, Limassol, B. Schätti, 27 May 2001 (roadkill). NMW 15185.1 (우), "Platraes, Troodos", Limassol, 1'400 m, F. Werner, May 1935 (paratype). ZFMK 48877 (ठ̊), $1 \mathrm{~km}$ northwest of Pano Platraes, Limassol, K. Osenegg \& S. Demetropoulos, 26 June 1988; ZFMK 51283 (ठ̋), Pano Panagia (Panayia), 1'000 m, Paphos, H. Wiedl, October 1989; ZFMK 51881 (ठ̋), Mt. Triphylos, approx. 3459' N $32^{\circ} 40^{\prime}$ E. Paphos, H. Wiedl. September 1990. Furthermore, MHNG 2618.100, consisting of a portion of a shed skin from the upper Livadi River area at approx. $35^{\circ} 04^{\prime} \mathrm{N}$ 32 36'E (c. $600 \mathrm{~m}$ ) in Paphos District, was used for verification of dorsal scale characters (apical pits, transverse position of reduction levels) and molecular studies (12S rDNA, see footnote 3).

External morphological data (pholidosis, length, dorsal colour pattern) are based on this material (ten complete specimens) and two male roadkills from the 
vicinity of Pano Platraes (Troodos road, “ca. $5 \mathrm{~km}$ südlich Troodos”) and Kakopetria (leg. S. Demetropoulos 1988) reported by Osenegg (1989: Tb. 24). Osteological characters were ascertained in MHNG 2453.60, MHNG 2618.99, and ZFMK 51881; additional teeth counts (right dentigerous bones) are based on HUJ 3331 (dentary, maxilla, palatinum), HUJ 3786 (dentary, maxilla), MHNG 2206.30 (maxilla), and NMW 15185.1 (maxilla).

Methods and definitions of terms used in the descriptive part and comparative section of this text are explained in Schätti $(1987,1988)$. The position of bilateral dorsal scale row reductions along the trunk is given in terms of absolute numbers of ventrals and as a percentage thereof (\%ven), and calculated on the basis of the average of right and left side counts. The length of the hemipenis and the $M$. retractor penis magnus are expressed in absolute numbers of subcaudals and as a percentage thereof (\%sub). Vertebra measurements used in this study are the length of the centrum (lc), length of neural crest (nc), least width of neural arch (wn), and the width across prezygapophyses (wp).

DNA sequences of two mitochondrial genes, cytochrome oxidase I (COI), and the small ribosomal subunit (12S rRNA), of 13 Palearctic and Afrotropical racers as well as the Oriental racer Coelognathus flavolineatus (Schlegel) (see Utiger, 2002) are from an earlier study (Schätti \& Utiger, 2001) and listed in the Appendix. Eight tissue samples belonging to four different taxa and frozen at $-80^{\circ} \mathrm{C}$ are new: Hierophis cypriensis (MHNG 2618.99, liver), H. gyarosensis (MHNG 2402.91 and 2401.92, Gyaros Island, Cyclades; muscle), H. spinalis (MHNG 2443.5, Wonju, Kangwon, S Korea; muscle; MVZ 211019, N shore Huang He, Shapotou, Yinnan Prefecture, China; liver), and $H$. viridiflavus (MHNG 2402.11, Chizé, Deux-Sèvres, France; muscle; MHNG 2402.66, Finaita, Sicily, Italy; muscle; MHNG 2402.83, Krk Island, Croatia; muscle). The corresponding Genbank accession numbers are AY 541502-541512.

DNA isolation, purification, polymerase chain reaction (PCR) and sequencing procedures were performed as described in Schätti \& Utiger (2001).

Because of considerable constraints in laboratory facilities, only one gene region, 12S rDNA, was analysed for the new specimens of Hierophis viridiflavus. These sequences were added to an alignment file consisting of two partially sequenced genes (COI and 12S rRNA) and a selection of 14 species from an earlier study (Schätti $\&$ Utiger, 2001). Where sequence information on the COI gene region was not available, characters were coded as "missing".

All phylogenetic analyses were performed with PAUP* version $4.0 \mathrm{~b} 10$ for Mac (Swofford, 1998). Neighbour joining (NJ, Saitou \& Nei, 1987) calculates gene distances based on the number of mutation events between all pairs of taxa. Under the present circumstances, the calculation of genetic distances between specimens with complete and incomplete sequence data is inappropriate because of different mutation properties within each gene region. In this case, maximum parsimony (MP) is a good alternative to $\mathrm{NJ}$ as it reconstructs a tree based on both gene regions. In addition, MP counts the mutation steps that occurred in the $12 \mathrm{~S}$ gene region between specimens with complete sequence data and those lacking information on COI. This gives a qualitatively satisfying result but deals with an underestimate of the intraspecific sequence variability of Hierophis viridiflavus compared to the branch lengths of the overall topology. 
Gaps in the $12 \mathrm{~S}$ sequence were treated as fifth character state. After a first run with heuristic search and tree-bisection reconnection (TBR) branch swapping, characters were weighted with the rescaled consistency index (RC, Farris, 1989) and a second heuristic search was performed. The weighting procedure was repeated once; subsequent weighting procedures did not alter the parameters of the resulting tree. Nonparametric bootstrap calculations (Felsenstein, 1985) with 1000 replicates were performed for unweighted as well as weighted characters.

The justification for including gaps and weighting characters is given in Utiger et al. (2002). Essentially, gaps supply additional phylogenetic information whereas weighting procedures favour characters which bear phylogenetic content. Using these measures, tree dependent (RC) and independent phylogenetic signals (tRASA, LyonsWeiler, 2001) intensify (Tb. 1).

TABLE 1. Sequence properties and tree reconstruction parameters.

\begin{tabular}{lrrrr}
\hline & \multicolumn{2}{c}{ gaps: missing } & & \multicolumn{2}{c}{ gaps: 5th character state } \\
\cline { 5 - 6 } \cline { 5 - 5 } & unweighted MP & & unweighted MP & weighted MP \\
\hline Length of sequence alignment (COI/12S) & $1016(407 / 609)$ & $1016(407 / 609)$ & $1016(407 / 609)$ \\
Total of variable characters (COI/12S) & $322(142 / 180)$ & $333(142 / 191)$ & $333(142 / 191)$ \\
- parsimony-informative (COI/12S) & $225(116 / 109)$ & $232(116 / 116)$ & $232(116 / 116)$ \\
Number of most parsimonious trees & 1 & 2 & 1 \\
Tree length & 918 & 956 & 267.38 \\
Rescaled consistency index (RC) & 0.232 & 0.242 & 0.548 \\
\hline
\end{tabular}

\section{RESULTS}

Hierophis cypriensis (Schätti, 1985)

MORPHOLOGY

Loreal and preocular single, two postoculars. Eight supraoculars (nine on left side of MHNG 2453.60), fourth and fifth (fifth and sixth) in contact with eye, sixth and seventh (seventh and eighth) largest. One anterior subocular situated between the third and fourth supralabial. One (holotype) or two anterior temporals, two or three scales in second row; lower anterior temporal vertically divided in NMW 15185.1. Ten sublabials, anterior four in contact with first inframaxillary, sixth largest. Anterior inframaxillaries slightly shorter than and more or less the same width as posterior pair, which is cranially separated by one row of small scales and caudally by two to four rows.

Ventrals in males 194-202 ( $\mathrm{n}=8)$, females 204-206 (3), subcaudals 123-133 (6) and 121-130 (3), respectively; anal plate divided. Dorsal scales smooth, with two apical pits; arranged in 17 longitudinal rows at the level of the tenth ventral and at midbody, 13 immediately prior to the vent. First reduction involving third and fourth row between ventrals 121 and 133 (62-68\%ven) in males and 126-132 (61-64\%ven) in 
females; second reduction (rows $6+7$ or $7+8$ ) situated between ventrals 136-159 (70$79 \%$ ven, of $\delta$ ) and 133-156 (66-73\%ven, 우 ㅇ) ${ }^{1)}$.

Total length in males 93,7 $(62,0+31,7) \mathrm{cm}(\mathrm{MHNG} 2618.99)$, females approx.

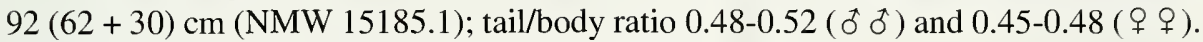
Presumed maximum length probably not exceeding $120 \mathrm{~cm}$.

Dorsal colouration in adults dark olive to anthracitic. Supraocular with a light streak running from the posterior border of the eye toward the frontal, and often also present along the lateral edge of the supraocular. Irregular light markings (dots and streaks) on the frontal and parietals. Supralabials mostly light except upper borders. Preoculars and postoculars yellowish white. Posterior temporal region with light dots. Throat pale yellow or off-white, irregularly mottled with fine greyish or sometimes black dots. Holotype with caudally converging dorsolateral nuchal stripes (Pl. 1). Anterior portion of neck usually somewhat lightened laterally. Forebody dorsally with fine white or creamish transverse bands. Posterior third of trunk and tail uniformly greyish olive (scales with lighter centres). Median part of venter pigmented with dark spots (less so anteriorly), with a fine whitish line along the ventral edges; lateral region invaded by dorsal colouration. ZFMK 48877 virtually black throughout the posterior three quarters of the underside. An irregular black line running along the median edges of the subcaudals.

The dorsal colour pattern is subject to ontogenetic change, i.e., juveniles (beige above) and subadult specimens (dorsum olive) have dark transverse blotches on the anterior two thirds of the body and an orange iridescent venter ( $\mathrm{H}$. Wiedl, pers. comm.). Illustrations of this species are found, for instance, in Schätti (1985), Gruber (1989), Osenegg (1989), and Schätti \& Sigg (1989b).

Maxillary teeth $14-16+2(n=6)$, with a distinct diastema and the posterior teeth enlarged (last offset laterad). Counts for other dentigerous bones 10-11 (palatinum, $\mathrm{n}=3$ ), 17-20 (pterygoid, 2), and 19-20 (dentary, 4). Palatine processus of maxilla comparatively long, lateral border more or less straight and ending in a distinct tip; posterior processus poorly developed. Lateral processus of palatinum stout, its posterior tip reaching insertion of choanal processus. Anterior portion of pterygoid narrow and slightly constricted behind the simple lateral processus. Parasphenoid not constricted at the basis, middle posterior border of basisphenoid somewhat convex (Fig. 1). Midbody vertebra ratios $(\mathrm{n}=2)$ are 1.38-1.58 (lc/wn), 0.74-0.80 (lc/wp), and 1.11-1.28 (nc/wn).

Hemipenis with a basal hook (Böhme \& Wiedl, 1994: Fig. 6), distally followed by a series of spines (less numerous on sulcate side), apex distinctly calyculate, borders of depressions spinose on asulcate side. Tip of apex in situ reaching to subcaudal 9-10 (7-8\%sub, $\mathrm{n}=4)$, M. retractor penis magnus inserting at subcaudal 30-32 (24$25 \%$ sub, $n=6)$.

1) Osenegg (1989: Table 24) gave 121 subcaudals for a male specimen (no. III). This figure as well as the reduction level to 15 dorsal scale rows are not included in the data because, strangely enough, subcaudal and reduction data for specimens III and V-VI are identical. Definitely, the reduction pattern of two specimens of the type series, i.e., MHNG 2206.30 and NMW 15185.1 (Osenegg, 1989: nos. V-VI) is erroneous. 


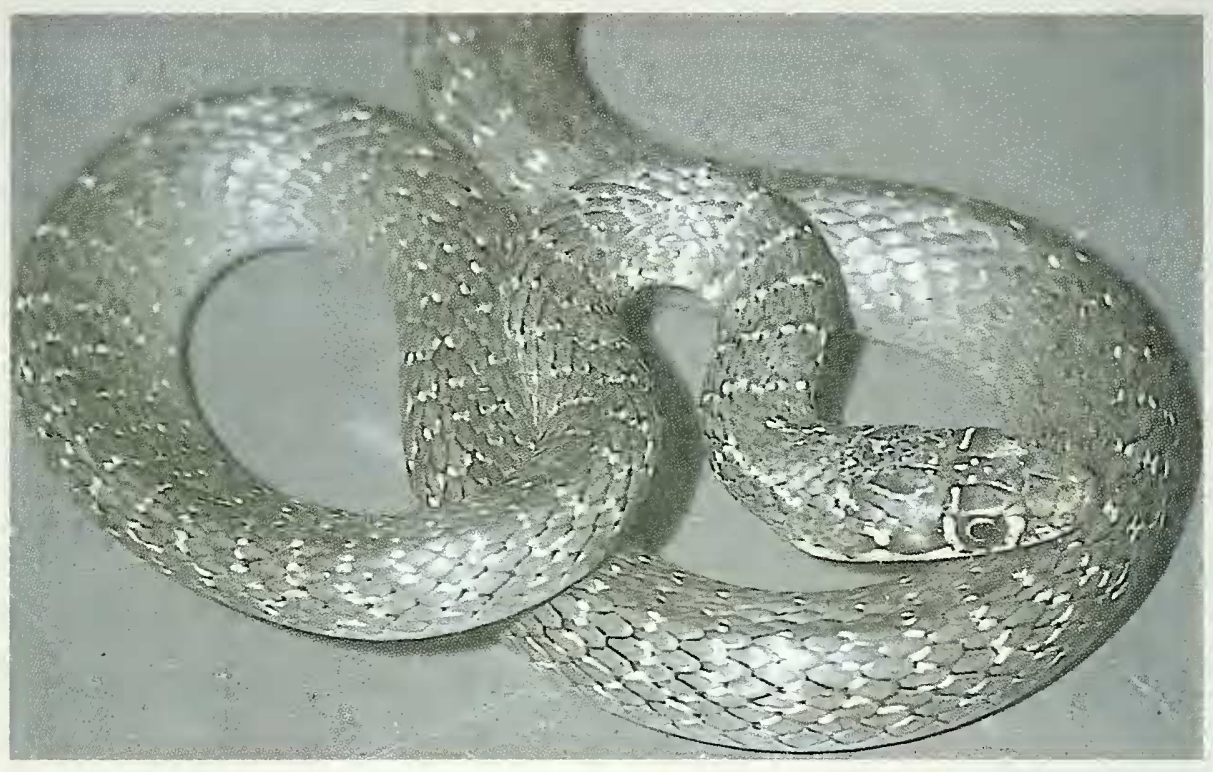

PLATE 1

Female holotype of Hierophis cypriensis (MHNG 2206.30).

\section{DisTRIBUTION AND ECOLOGY}

The Cyprus racer is reported from Limassol District, southwestern Nicosia (Lefkosa), and the Stavros woods in eastern Paphos, i.e., the Troodos massif and its foothills in western Cyprus (Fig. 3) ${ }^{2)}$.

Most records are from pine forest with abundant coppice between 400 to 1'700 m a.s.l. near Pano Platraes (H. Wiedl, pers. comm.). The Cyprus racer also occurs at lower elevations, viz. below $250 \mathrm{~m}$ as exemplified by specimens collected in the immediate hinterland of Limassol (HUJ 3331 and 3786, MHNG 2618.99).

Based on the limited number of preserved specimens and field observations, Hierophis cypriensis might appear to be either an uncommon, secretive, or locally restricted species. However, the Cyprus racer seems to be fairly common at least in the Xyliatos dam area (c. $550 \mathrm{~m}$ ) and the Lagoudhera valley situated on the northern Troodos foothills at approx. $35^{\circ} 00^{\prime} \mathrm{N} 33^{\circ} 02^{\prime} \mathrm{E}$ in Nicosia District. There, from a total of 58 field observations during three years, 47 individuals found in the immediate surroundings of the dam were usually observed between 10 a.m. and 3 p.m., mostly from July to September, with a single record $50 \mathrm{~m}$ from the water in March (Blosat, 1998).

Virtually all specimens housed in scientific collections and many field observations are from habitats with dense bushy vegetation close to creeks and rivers. In many

\footnotetext{
2) Apart from records shown on Böhme \& Wiedl's (1994: Fig. 5) map, Wiedl found Hierophis cypriensis "together with Telescopus fallax" at Kámpos and "Chalkistra" (Tsakistra, $35^{\circ} 01^{\prime} 25^{\prime \prime} \mathrm{N} 32^{\circ} 43^{\prime} 27^{\prime \prime} \mathrm{E}$ ) in western Nicosia District (Böhme \& Wiedl, 1994: 40), a few kilometres roughly north of Kykko Monastery on the Agios Mámas road.
} 


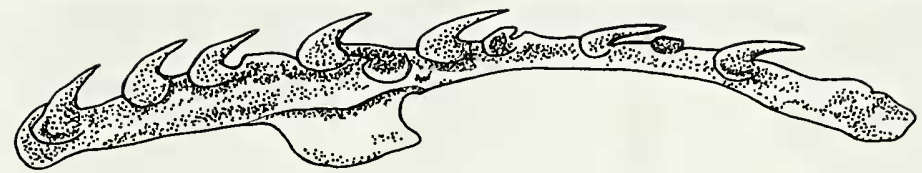

A

B
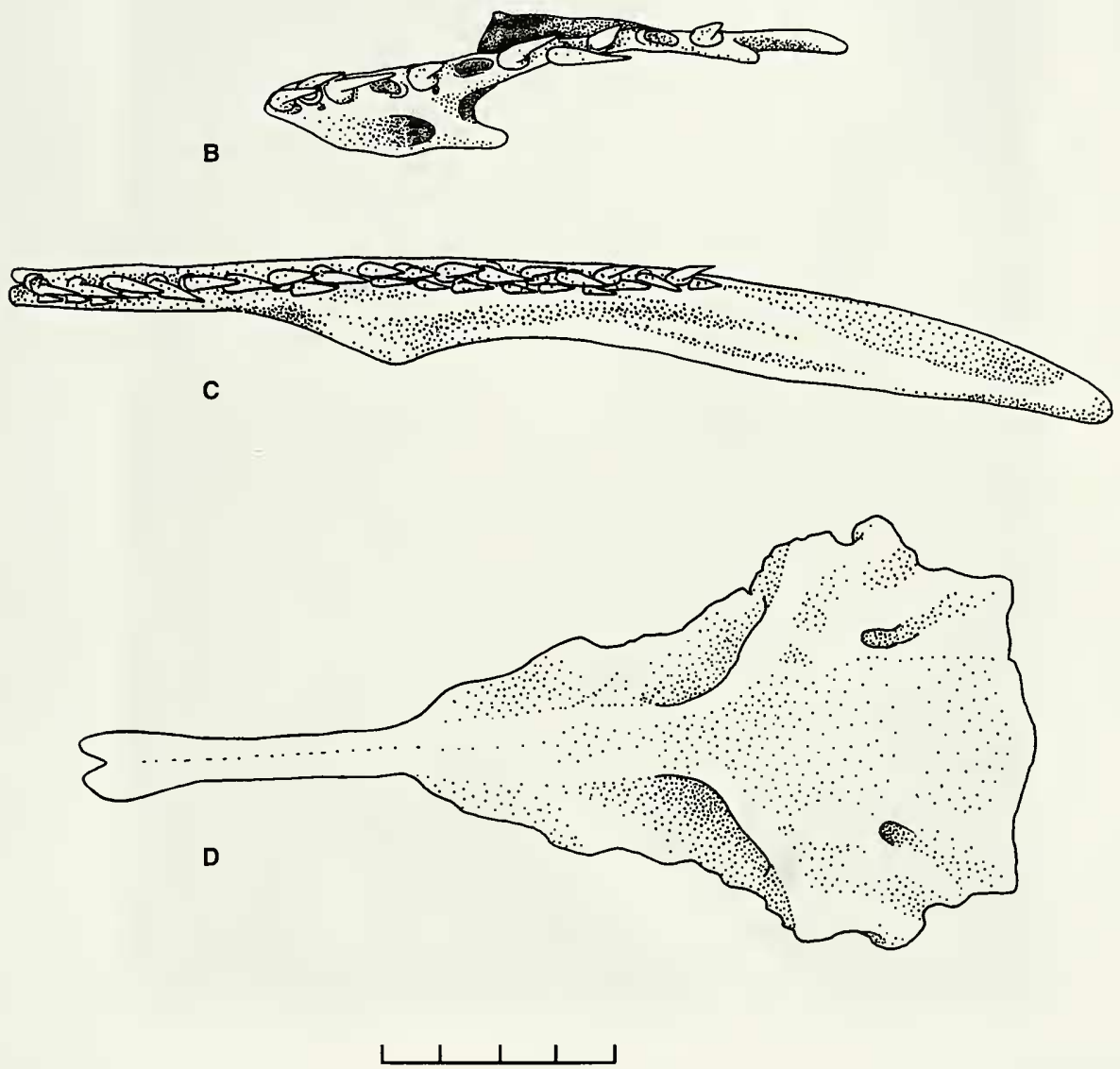

FIG. 1

Skull bones of Hierophis cypriensis: Left maxilla (A), right palatinum (B), right pterygoid (C), and basisphenoid ( $D$, parasphenoid broken, reconstructed). Scale equals $2 \mathrm{~mm}$. Drawings by Corinne Charvet (A: MHNG 2453.60) and Beatrice Naef (B-D: ZFMK 51881).

of these places, Hierophis cypriensis is sympatric with Macrovipera (or Daboia) lebetina (L.). In the Xyliatos dam area, the Cyprus racer is found in the same habitat as Natrix natrix cypriaca (Hecht).

Hierophis cypriensis preferably feeds on smaller species of lizards, in particular Ablepharus kitaibelii (Bibron \& Bory) and Ophisops elegans (Ménétries), and green 


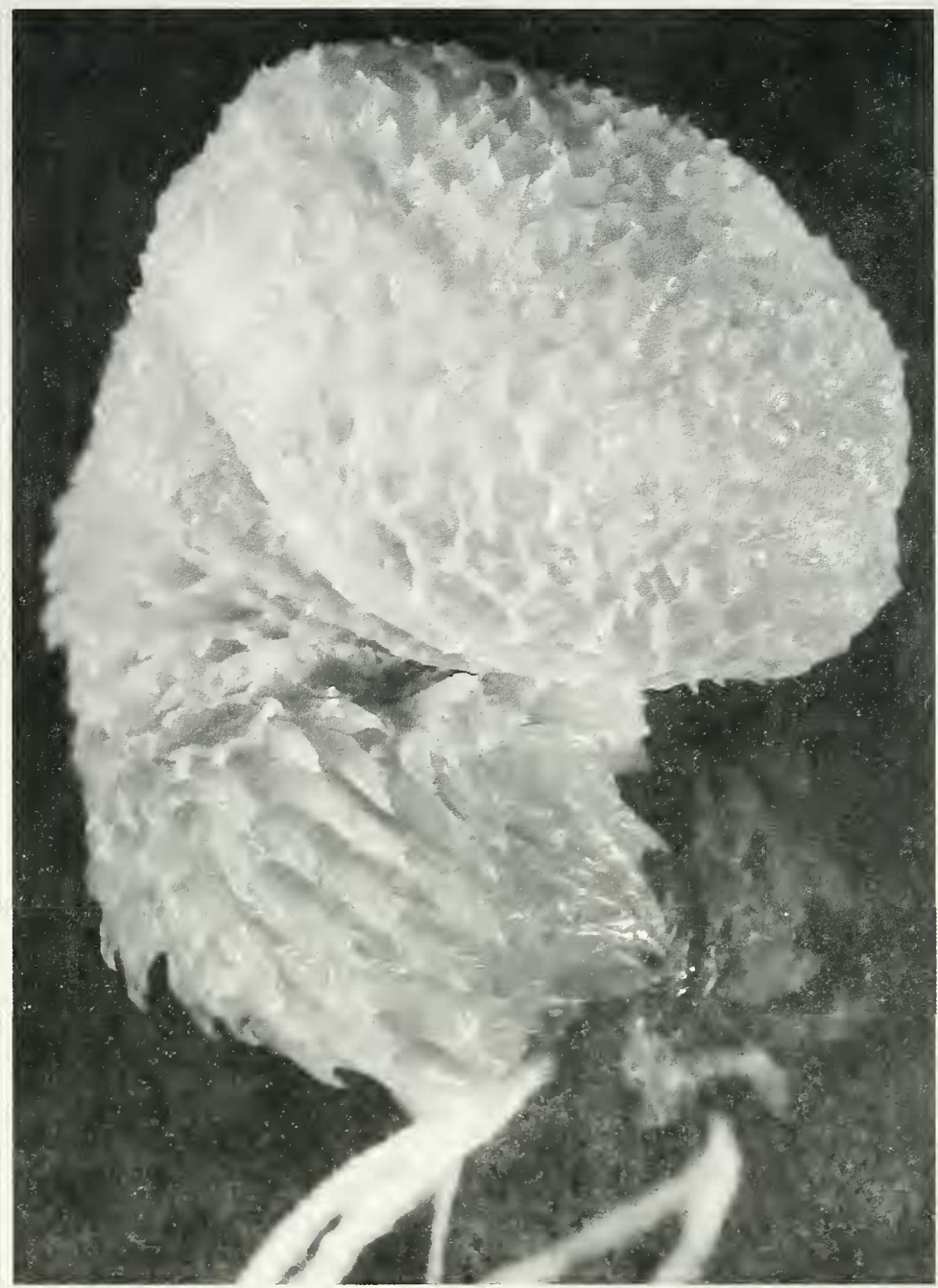

FIG. 2

Hierophis cypriensis: Lateral view of right hemipenis of MHNG 2618.99 (roadkill). Photograph by Claude Ratton.

frogs, i.e., Rana cf. bedriagae Camerano (see Plötner et al., 2001). Blosat (1998) observed one specimen that captured a "Lacertide", probably Lacerta laevis troodica Werner, and an incidence of ophiophagy (Natrix natrix cypriaca). The holotype regurgitated a centipede. In captivity, $H$. cypriensis also preys on mammals, i.e., small mice (personal observation).

Contrary to most congeneric species, Hierophis cypriensis is a placid snake that does not bite upon collecting. In one instance, the Cyprus racer was found feigning death (W. Teschner, in litt.). Since this was observed on a road, it cannot be ruled out that a car had driven over the specimen before being encountered by the correspondent. 


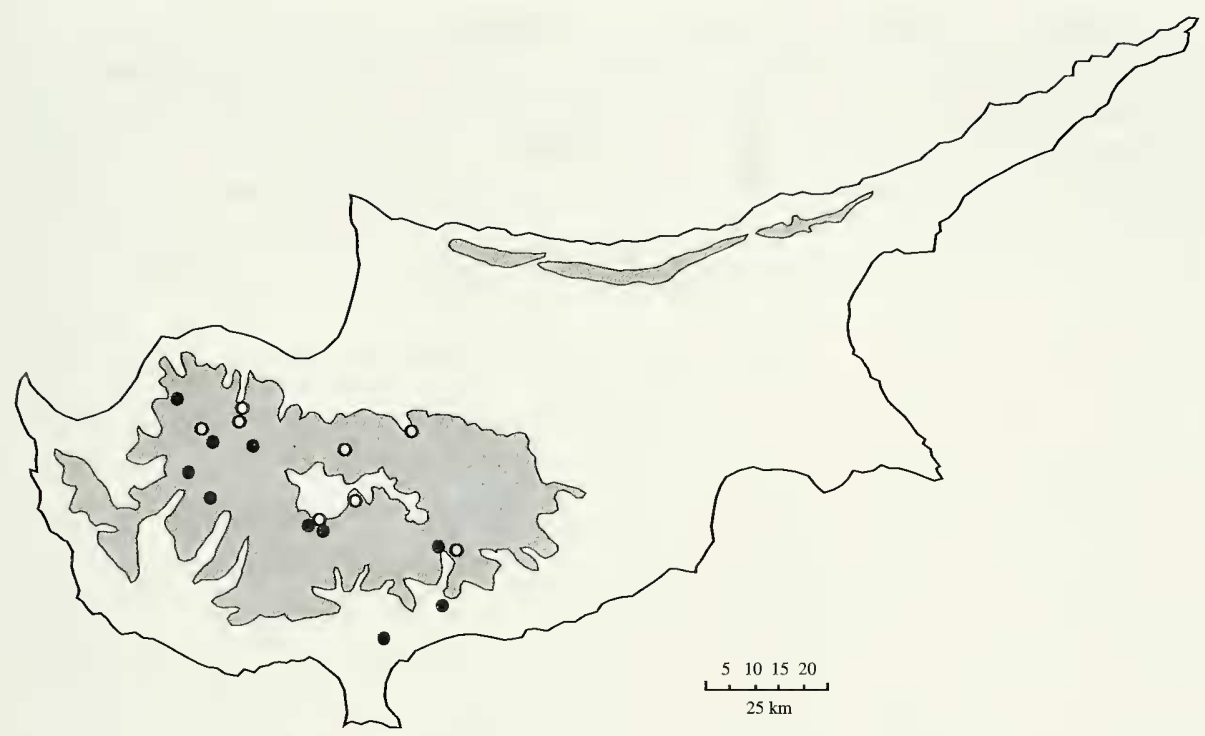

FIG. 3

Known distribution of Hierophis cypriensis. Solid circles denote examined specimens with precise locality data and MHNG 2618.100 from the upper Livadi River, Paphos (see Material and Methods and footnote 3 ). Open symbols correspond to four localities in the central Troodos (Kakopetria, Platania, and "ca. $5 \mathrm{~km}$ südlich Troodos") and eastern Paphos District (Stavros tis Psokas) cited in Osenegg (1989: Fig. 44) as well as the Xyliatos dam area, an unspecified station near the type locality (Böhme \& Wiedl, 1994: Fig. 5), and Kampos and Tsakistra (see footnote 2). Elevations from $400 \mathrm{~m}$ to 1'200 m hatched, areas over 1'200 $\mathrm{m}$ in the central Troodos blank. Map partly redrawn from Böhme \& Wiedl (1994).

\section{ZOOGEOGRAPHY AND RELATIONSHIPS}

Böhme \& Wiedl (1994) presumed that Hierophis cypriensis had been "existing much longer on Cyprus than the rest of the herpetofauna." Arguing that "snakes are generally primarily absent from oceanic islands", these authors though that "the case of Coluber cypriensis in particular would corroborate" the assumption of a land bridge. This alludes to Haas (1952) who postulated a terrestrial connection across the Golf of Iskenderun in the Pliocene or early Quaternary (see, e.g., Schmidt, 1960; Spitzenberger, 1979). However, there is no geological evidence for a land bridge during that period. Rather, Cyprus is isolated from the surrounding mainland since the Upper Miocene salinity crisis of the Mediterranean (Hsü, 1972) as assumed by Schätti \& Sigg (1989a).

Hierophis cypriensis is most similar to $H$. gemonensis and $H$. viridiflavus with respect to certain osteological features (Fig. 1) as, for instance, the comparatively long palatine processus of the maxilla (also found in $H$. jugularis but not in $H$. caspius). $H$. cypriensis and $H$. gemonensis have more maxillary teeth (16-19 vs. 12-16) than the remaining species of this genus. These two species as well as $H$. spinalis (in prep.) possess an enlarged spine (hook) at the basis of the hemipenis. 
Based on morphological evidence and preliminary molecular data (mtDNA sequences), Schätti \& Utiger (2001: 934, 939) considered Hierophis cypriensis to be "most closely related to congeneric European species" ${ }^{3}$ ). The present results (Fig. 4) confirm sister species status of $H$. cypriensis vis-à-vis the western Mediterranean $H$. viridiflavus and $H$. gemonensis, viz. the Balkans and European whip snake.

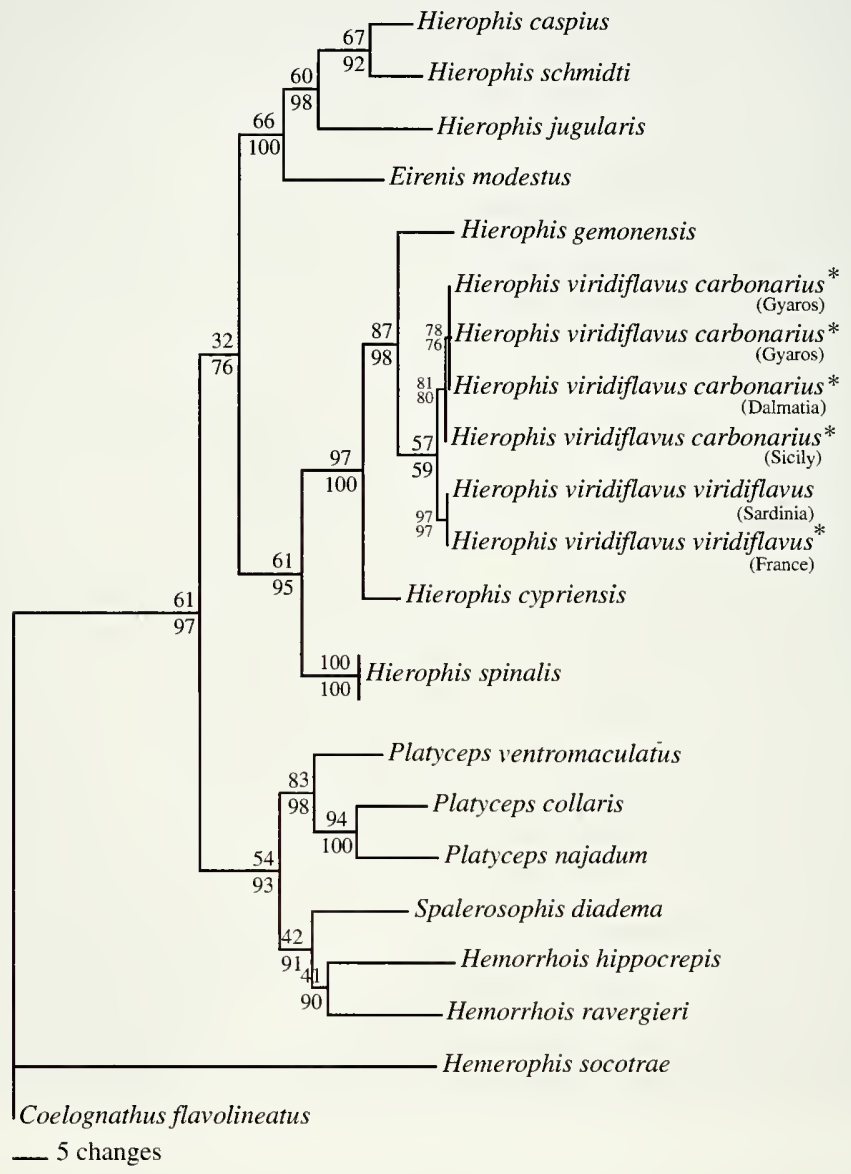

FIG. 4

Most parsimonious tree from a weighted MP analysis of two partial gene sequences, COI and $12 \mathrm{~S}$ rDNA. Numbers above branches indicate bootstrap values from an unweighted, those below from a weighted MP analysis. Asterisks denote specimens lacking COI sequence data (see also footnote 3).

3) Schätti \& Utiger (2001) examined a fragment of the 12S rDNA subunit of MHNG 2618.100 (epidermal skin, see Material and Methods). The sequence shows only small difference ( 2 out of 592 base pairs) vis-à-vis MHNG 2618.99. The specimen was not used for the phylogenetic recontruction because the lack of the COI partition significantly lowered the resolution of the tree topology. 
Molecular data and considerable morphological divergence of Hierophis cypriensis (e.g., dorsal colour pattern, paravertebral reductions, processi of dentigerous bones, general shape of basisphenoid) from congeneric, and in particular the most closely related western Mediterranean, species support the theory of the isolation of Cyprus for the last approx. 5,2 my.

Apart from Macrovipera schweizeri (Werner) from the Cyclades, Hierophis cypriensis is the only endemic Mediterranean insular snake species.

\section{Hierophis viridiflavus (Lacépède, 1789)}

Coluber gemonensis gyarosensis Mertens, 1968 syn. nov.

The systematic status and specific allocation of Coluber gemonensis gyarosensis Mertens, 1968 have been a matter of controversy (see Introduction). Specific status (Schätti, 1988) was accorded based on morphological differences vis-à-vis two whip snake species (Hierophis caspils, H. gemonensis) distributed in the Aegean region. Böhme (1993) considered the melanotic taxon from Gyaros to be the rarest European snake species.

Racers from Gyaros most strikingly resemble the European whip snake, Hierophis viridiflavus, in general appearance, habitus, and morphology (Schätti, 1988). In fact, the insular taxon cannot be distinguished from $H$. viridiflavis and molecular data (Fig. 4) clearly demonstrate that Coluber gemonensis gyarosensis Mertens, 1968 is a junior synonym of $H$. viridiflavus (Lacépède, 1789).

The western Mediterranean Hierophis viridiflavis has a continuous range from the Pyrenees region (NE Spain) to northern France, Luxembourg, and western Switzerland as well as throughout the Appenine Peninsula, Ticino, and eastward to northern Dalmatia. The species is widespread in the Tyrrhenian Sea, found on Sicily and many surrounding islands and islets, Malta, Gozo, and in the Adriatic Sea (Krk, Tremiti Islands). The isolated Aegean occurrence on Gyaros is most probably due to human introduction in historical times. To conclude from our molecular data (Fig. 4), $H$. viridiflavus was most likely transported to Gyaros from the northern Adriatic region.

Gyaros (Gioura, Yíoura), nowadays known as Yiaros or Nisos, is a mountainous island (up to $490 \mathrm{~m}$ a.s.l. in the central part) of ca. $20 \mathrm{~km}^{2}$ at $37^{\circ} 37^{\prime} \mathrm{N} 24^{\circ} 43^{\prime} \mathrm{E}$ in the Cyclades, roughly $15 \mathrm{~km}$ northwest of Syros about halfway between Kea and Tinos. From the beginning of our era until the Middle Ages, the island was a haven for marauding corsairs who attacked merchant ships throughout the Aegean. During the Roman Imperial epoch, Gyaros served as a place of exile.

All surrounding larger islands (viz., Andros, Kea, Kythnos, Syros, and Tinos) are inhabited by Hierophis caspilus, an eastern Mediterranean species widespread in the Aegean Sea and found on all larger Cyclade islands surrounding Gyaros (e.g., Schätti, 1988; Szczerbak \& Böhme, 1993). The absence of the Caspian whip snake from Gyaros may have favoured the colonization of this island by $H$. viridiflavis.

External morphological characters of Hierophis viridiflavus analysed by Schätti \& Vanni (1986) hardly allow a distinction between typical and melanotic populations commonly referred to $H$. v. carbonarius (Bonaparte). These authors considered this phenotype as a colour morph of the European whip snake, $H$. viridiflavis. Based on 
molecular data, our limited sample shows genetic separation of typically coloured specimens (France, Sardinia) and melanotic individuals from Dalmatia (Krk), Sicily, and Gyaros Island. Pending studies using specimens from further regions, this result may justify the revalidation of $H$. v. carbonarius for populations from northeastern Italy and Dalmatia, the southern Appenine Peninsula including islands such as Sicily and Malta, and the isolated Gyaros population.

\section{ACKNOWLEDGEMENTS}

The junior author expresses his gratitude to Nicolas E. Arnold (London), Wolfgang Böhme (Bonn), Franz Tiedemann (Vienna), and Yehudah L. Werner (Jerusalem) for approving the loans of specimens in their respective care. Theodore J. Papenfuss (Berkeley, MIZ) and J. Robert Macey (Walnut Creek) supplied tissue samples. Lara Modolo, Wolfgang Scheffrahn, Claudia Zebib-Brunner (all Zurich), and Jennifer Pastorini (New York) supported the laboratory work, and Vincent Ziswiler and Paul Ward (Zurich) provided the facilities. A most special thank you to Corinne Charvet (Geneva) for technical assistance. We feel obliged to Walter Teschner (Wuppertal) and "Snake George" Hansjörg Wiedl (Paphos) for field observations on the Cyprus racer. Regula Böniger, Claudia Fischer, Barbara Straub (all Zurich) helped with bibliographical research, and Beatrice Naef (Geneva) prepared some of the drawings.

\section{REFERENCES}

Blosat, B. 1998. Morphologie, Aut- und Populationsökologie einer Reliktpopulation der zypriotischen Ringelnatter, Natrix natrix cypriaca (Hecht, 1930). Bonn, Inaugural-Disseration, $174 \mathrm{pp}$.

BöHME, W. 1993. Coluber gyarosensis Mertens, 1968 - Gyaros-Pfeilnatter (pp. 111-114). In: BöHME, W. (ed.). Handbuch der Reptilien und Amphibien Europas, Band 3/I. Wiesbaden, Aula-Verlag, $479 \mathrm{pp}$.

BöHME, W. \& WIEDL, H. 1994. Status and zoogeography of the herpetofauna of Cyprus, with taxonomic and natural history notes on selected species (genera Rana, Coluber, Natrix, Vipera). Zoology in the Middle East 10: 31-52.

BonAPARTE, C. L. 1834. Coluber leopardinus [4 unnumbered pages]. In: Iconografia della Fauna Italica per le quattro classi degli animali vertebrati [1832-1841]. II. Amfibi [Fasc. VII, punt. 38]. Roma, Salviucci.

FARRIS, J. S. 1989. The retention index and the rescaled consistency index. Cladistics 5: 417-419.

Felsenstein, J. 1985. Confidence limits on phylogenies: an approach using the bootstrap. Evolution 39: 783-791.

Gruber, U. 1989. Die Schlangen Europas und rund ums Mittelmeer. Kosmos-Naturführer. Stuttgart, Franckh'sche Verlagsbuchhandlung, 248 pp.

HAAs, G. 1952. Remarks on the origin of the herpetofauna of Palestine. Revue de la Faculté des Sciences de l'Université d'Istanbul (B) 17 (2): 95-105.

Hsü, K. 1972. When the Mediterranean dried up. Scientific American 227: 27-36.

LACÉPÈDE, B. G. E., Comte de 1789. Histoire Naturelle des Quadrupèdes ovipares et des Serpens. Vol. II. Paris, Hôtel de Thou, $9+20+144+474$ pp.

LiNNAEUS, C. 1758. Systema naturae per regna tria naturae, secundum classes, ordines, genera, species, cum characteribus, differentiis, synonymis, locis. Vol. I (editio decima, reformata). Holmiae [Stockholm], L. Salvii, IV + 823 [+ 1] pp.

LYONS-WeILER, J. 2001. RASA 3.0 Turbo for the Macintosh. http://bio.uml.edu/LW/RASA.html 
MERTENs, R. 1968. Eine schwarze Zornnatter von den Cycladen: Coluber gemonensis gyarosensis n. subsp. Senckenbergiana biologica 49 (3/4): 181-189.

OseneGG, K. 1989. Die Amphibien und Reptilien der Insel Zypern. Bonn, Diplomarbeit, Friedrich-Wilhelms Universität, $200 \mathrm{pp}$.

Plötner, J., OHST, T., BöHme, W. \& SCHREIBER, R. 2001. Divergence in mitochondrial DNA of Near Eastern water frogs with special reference to the systematic status of Cypriote and Anatolian populations (Anura, Ranidae). Amphibia-Reptilia 22 (4): 397-412.

SAITOU, N. \& NeI, M. 1987. The neighbor-joining method: a new method for reconstructing phylogenetic trees. Molecular Biology and Evolution 4: 406-425.

SCHÄтTI, B. 1985. Eine neue Zornnatter aus Zypern, Coluber cypriensis n. sp. Revue suisse de Zoologie 92 (2): 471-477.

SCHÄтTI, B. 1986. Morphological evidence for a partition of the snake genus Coluber (pp. 235238). In: RočEK, Z. (ed.). Studies in Herpetology (Proceedings of the European Herpetological Meeting, 1985). Prague, Charles University, XXVIII + 754 pp.

SCHÄTTI, B. 1987. The phylogenetic significance of morphological characters in the Holarctic racers of the genus Coluber (Reptilia, Serpentes). Amphibia-Reptilia 8 (4): 401-415.

SCHÄTTI, B. 1988. Systematik und Evolution der Schlangengattung Hierophis Fitzinger, 1843. Zürich, Inaugural-Dissertation, $50 \mathrm{pp}$.

SCHÄтTI, B. 1993. Coluber Linnaeus, 1758 - Zornnattern (pp. 69-71). In: BöHME, W. (ed.). Handbuch der Reptilien und Amphibien Europas, Band 3/I. Wiesbaden, Aula-Verlag, 479 pp.

SCHÄtTI, B. \& SigG, H. 1989a. Die Herpetofauna der Insel Zypern. 1. Die herpetologische Erforschung und Amphibien. Herpetofauna (Weinstadt) 11 (61): 9-18.

SCHÄтTI, B. \& SigG, H. 1989b. Die Herpetofauna der Insel Zypern. 2. Schildkröten, Echsen und Schlangen. Herpetofauna (Weinstadt) 11 (62): 17-26.

SCHÄTti, B. \& Utiger, U. 2001. Hemerophis, a new genus for Zamenis socotrae Günther, and a contribution to the phylogeny of Old World racers, whip snakes, and related genera (Reptilia: Squamata: Colubrinae). Revue suisse de Zoologie 108 (4): 919-948.

SchätTI, B. \& VANNI, S. 1986. Intraspecific variation in Coluber viridiflavus Lacépède, 1979, and validity of its subspecies (Reptilia, Serpentes, Colubridae). Revue suisse de Zoologie 93 (1): 219-232.

Schätтा, B. \& WILson, L. D. 1986. Coluber. Catalogue of American Amphibians and Reptiles 399: 1-4.

Schmid, W. F. 1960. Zur Struktur und Tektonik der Insel Cypern. Geologische Rundschau 50: 375-395.

SpITZenberger, F. 1979. Die Säugetierfauna Zyperns. Teil II: Chiroptera, Lagomorpha, Carnivora und Artiodactyla. Annalen des Naturhistorischen Museums Wien 82: 439-465.

SWOFFORD, D. L. 1998. PAUP*: phylogenetic analysis using parsimony (and other methods). Version $4.0 \mathrm{~b} 10$ for Mac. Sunderland, Sinauer.

SzCZERBAK, N. N. \& BöHME, W. 1993. Coluber caspius Gmelin, 1789 - Kaspische Pfeilnatter oder Springnatter (pp. 83-96). In: BöHME, W. (ed.). Handbuch der Reptilien und Amphibien Europas, Band 3/I. Wiesbaden, Aula-Verlag, 479 pp.

UTIGER, U. 2002. Molecular phylogeny of the Oriental colubrid genus Coelognathus Fitzinger, 1843, and a contribution to the systematics of Holarctic racers and ratsnakes (Reptilia: Squamata: Serpentes). University of Zürich, Ph. D. thesis [part.], 73 pp.

Utiger, U., Helfenberger, N., Schätti, B., Schmidt, C., Ruf, M. \& Ziswiler, V. 2002. Molecular systematics and phylogeny of Old and New World ratsnakes, Elaphe auct., and related genera (Reptilia, Squamata, Colubridae). Russian Journal of Herpetology 9 (2): 105-124. 
APPENDIX. Genbank numbers of specimens examined by Schätti \& Utiger (2001) used in this study (COI/12S). Coelognathus flavolineatus (AY039200/AY039162); Eirenis modestus (AY039181/AY039143); Hemerophis socotrae (AY039167/ AY039129); Hemorrhois hippocrepis (AY039194/AY039156), H. ravergieri (AY039193/AY039155); Hierophis caspius (AY039164/AY039126), H. gemonensis (AY039183/AY039145), H. jugularis (AY039188/ AY039150), H. schmidti (AY039197/AY039159), H. viridiflavus (AY039175/AY039137); Platyceps collaris (AY039195/AY039157), P. najadum (AY039179/AY039141), P. ventromaculatus (AY039172/AY039134); Spalerosophis diadema (AY039182/AY039144). 